\title{
Electro-Catalytic Activities of Binary Nano-Composites of Pt and Nano- Carbon/Multiwall Carbon Nanotube for Methanol Electro-Oxidation
}

\author{
R.N. Singh ${ }^{*}, 1$, R Awasthi ${ }^{1}$ and S.K. Tiwari ${ }^{2}$ \\ ${ }^{I}$ Department of Chemistry, Faculty of Science, Banaras Hindu University, Varanasi - 221005, India \\ ${ }^{2}$ National Metallurgical Laboratory, Jamshedpur- 831007, India
}

\begin{abstract}
Binary nano-composites of Pt and nano-carbon (NC) and Pt and multiwalled carbon nanotube (MWCNT) have been prepared with varied compositions ranging between 20 and $80 \mathrm{wt} \% \mathrm{Pt}$ and investigated them as electrocatalysts for methanol oxidation. The study shows that with the increase in $\mathrm{wt} \%$ of $\mathrm{NC}$, the apparent electro-catalytic activity of the composite catalyst increases initially, reaches maximum at about $40 \mathrm{wt} \% \mathrm{NC}$ and decreases thereafter. However, the anodic peak current value, estimated as per $\mathrm{mg}$ of Pt present in the composite, increases gradually with increasing $\mathrm{wt} \%$ of $\mathrm{NC}$ in the composite. The electrochemical active surface area (EASA) value for Pt in the composite electrode also increases with increasing the carbon composition in the composite. Almost similar effect of the MWCNT addition on the electro-catalytic activity is also observed in the case of Pt-MWCNT composite. Results have shown that an incorporation of carbon (NC/MWCNT) improves both the geometrical as well as the electronic properties of Pt.
\end{abstract}

Keywords: Nano-composites, nano-carbon, multiwalled carbon nanotubes, methanol electro-oxidation, electro-catalytic activity.

\section{INTRODUCTION}

Direct methanol fuel cell (DMFC) is presently considered as the most promising power source for the transportation and portable electronic devices because it has high energy conversion efficiency, low operating temperature, and ease of handling [1]. However, the commercialization of DMFC is obstructed due to sluggish kinetics of methanol oxidation reaction (MOR) [2]. Pt and Pt-based alloys are the best catalysts for the MOR [3-5], but they are very costly and undergo poisoning by the oxidation intermediates, particularly CO molecule [6, 7]. To reduce the cost vis-à-vis enhance the activity, the catalyst supporting strategy is increasingly adopted. The supported catalysts generally showed higher activities and stability at reduced mass. For the purpose, carbon is considered as an ideal support material for precious metals. The literature reveals that up to 1990, carbon blacks (e.g. Vulcan XC-72) were almost exclusively used as catalyst supports in low temperature fuel cells because of its low cost and high availability [8]. To improve the electrochemical activity and stability of the catalyst further, many new carbon materials such as graphite nanofibers [9-12], carbon nanocoils [13, 14], carbon nanotubes (CNTs) $[1,15,16]$ have recently been tested as supports for fuel cells catalysts. Compared to carbon blacks, these new carbon materials are different both at nanoscopic level in terms of their structural conformation (for example nanotubes) and pore texture (for example meso pore carbons) and/or at the macroscopic level in terms of their form (for example microspheres).

*Address correspondence to this author at the Department of Chemistry, Faculty of Science, Banaras Hindu University, Varanasi - 221005, India; Tel: +91-542-6701596; Fax: +91-542-2368127;

E-mail: rnsbhu@rediffmail.com
It is known $[1,2,9,17]$ that the introduction of carbon support greatly influences the Pt particle size and hence the electro-catalytic activities of the catalysts. For instance, Umeda et al. [17] prepared carbon supported platinum catalysts with Pt loading of 10, 20,30, 40 and $50 \mathrm{wt} \%$ and demonstrated that the Pt size increases gradually with the increase in Pt loading. For methanol oxidation in $1.0 \mathrm{~N}$ $\mathrm{H}_{2} \mathrm{SO}_{4}, 30 \mathrm{wt} \% \mathrm{Pt} / \mathrm{C}$ exhibited the highest electro-catalytic activity, whereas the $50 \mathrm{wt} \% \mathrm{Pt} / \mathrm{C}$ showed extremely small current. In a similar study, Hall et al. [2] also observed that the Pt particle size increases gradually from 2.0 to $5.8 \mathrm{~nm}$ as Pt content increases from $20 \%$ to $80 \mathrm{wt} \%$. Similar studies for optimizing amount of the support in the case of composite of Pt with new carbon materials such as carbon nanotubes are scarce in the literature. Only recently, Bessel et al. [9] have reported that $\mathrm{Pt}$ supported on graphite nanofibers exhibited higher activity and stability compared to that supported on Vulcan XC-72 carbon under similar experimental conditions. Liang et al. [1] found that Pt particle size increased with metal loading; however, the increase was more sensitive on the MWCNT support than that on Vulcan carbon black under condition of same Pt loadings.

We have synthesized binary nano-composites of $\mathrm{Pt}$ and nano-carbon (NC) and Pt and MWCNT covering a wide range of Pt compositions from 20 to $80 \mathrm{wt} \%$ and investigated their physicochemical and electrochemical properties towards MOR. The study is aimed to compare the effect of two forms of carbon supports as well as their percent content on the structural and electro-catalytic properties of $\mathrm{Pt}$ catalyst in relation to MOR. Details of the results of the investigation are presented in the present paper. 


\section{EXPERIMENTAL}

\subsection{Preparation of Composites}

Nano-composites of Pt and NC (Aldrich, 99\%+, Pr. No. 633100 , particle size $\leq 30 \mathrm{~nm} \&$ BET surface area $>100 \mathrm{~m}^{2}$ $\mathrm{g}^{-1}$ )/MWCNT (Aldrich, Pr. No. 659258, dia. $=110-170 \mathrm{~nm}$ $\&$ length $=5-9$ micron) were synthesized by $\mathrm{NaBH}_{4}$ reduction method [18]. For the purpose, the required amount of activated NC/MWCNT (4-16 mg) were first dispersed in $2 \mathrm{ml}$ double distilled water under ultrasonic stirring for $1 \mathrm{hr}$ and then added the required amount of chloroplatinic acid (Aldrich, Pr. No. 206083-1G) precursor (10.62-53.1 mg) and again ultrasonicated for $1 \mathrm{hr}$. To this, an excess of $\mathrm{NaBH}_{4}$ (Sigma-Aldrich, Pr. No.452874) solution was added under vigorous stirred condition to carry out the complete reduction of metal ions. For addition of the Pt precursor salt, a stock solution of chloroplatinic acid in acidified redistilled water $\left(20 \mathrm{mg} \mathrm{ml}^{-1}\right)$ was used. After completion of the reduction process, the product was separated through centrifugation, repeatedly washed with double distilled water so as to remove $\mathrm{Cl}^{-}$ions and finally dried overnight in a vacuum oven at $100^{\circ} \mathrm{C}$. Thus the desired $\mathrm{Pt}-\mathrm{C}$ composites with varying percentage of $\mathrm{C}$, namely 20,30,40,60 and 80 $\mathrm{wt} \%$ were obtained. As mentioned earlier [18, 19], the activation of carbon (NC/MWCNT) was carried out by refluxing it in concentrated $\mathrm{HNO}_{3}$ for $5 \mathrm{~h}$. For Comparison, pure $\mathrm{Pt}$ was also obtained by the reduction of chloroplatinic acid solution as described above.

\subsection{Preparation of Electrodes}

The catalyst (composite) was dispersed in a ternary mixture of double distilled water, ethanol and isopropanol $(1: 1: 2)$. The mixture was then sonicated to get a homogenous suspension. It was then dropped (2-3 drops) on a pretreated glassy carbon (GC) plate through capillary and dried. Prior to use as the support for the catalyst over layer, GC plates were first polished well on a polishing machine using a microcloth pad and alumina powder and then dipped in 0.2 $\mathrm{M} \mathrm{H}_{3} \mathrm{PO}_{4}$ for $5 \mathrm{~min}$, degreased in acetone by ultrasonication, washed with distilled water and dried. Finally, one drop of $1 w t \%$ Nafion solution (Alfa Aesar) was dropped over the dried catalyst layer to stabilize it. The electrodes, thus obtained, were finally irradiated with microwave (800 Watt) for 1 minute. Electrical contact with catalyst film was made as already describe elsewhere [20].

\subsection{Material Characterization}

X-ray diffraction (XRD) patterns of pure $\mathrm{Pt}$ and composite films as obtained on GC were recorded on an $\mathrm{X}$ ray diffractometer (Thermo Electron) at a sweep rate of $3^{\circ}$ $\min ^{-1}$ using $\mathrm{Cu} \mathrm{K} \alpha$ as the radiation source $(\lambda=1.541841 \AA)$. Morphology of the catalytic films was studied by a transmission electron microscope (TECNAIG ${ }^{2}$ FEI Neederland). Samples for TEM analyses were prepared by dispersing the catalyst into double distilled water, transferring a drop of this suspension onto a colloidal coated copper grid, and subsequently drying in air.

The AFM study was made for two catalysts, Pt$20 \mathrm{wt} \% \mathrm{NC}$ and $\mathrm{Pt}-80 \mathrm{wt} \% \mathrm{NC}$. Prior to the study, the moisture content of the sample, if any, was removed by keeping it under incandescent lamp for $2 \mathrm{~h}$. The dried powders of the catalysts were then dispersed on freshly cleaved mica surface. The excess powders were removed by hand blower and again kept under lamp for $1 \mathrm{~h}$. The samples were investigated in non contact force mode of Atomic Force Microscopy (Model SPA 400, SEICO, Japan).

\subsection{Electrochemical Study}

Electrochemical studies were carried out in a conventional three-electrode single compartment Pyrex glass cell. The potential of the working electrode was measured against the SCE electrode $(0.242 \mathrm{~V} v s$. S H E). The counter electrode was a Pt plate of $\sim 8 \mathrm{~cm}^{2}$. The potential values mentioned in the text are referred against the SCE electrode only. Electrochemical studies, namely, cyclic voltammetry (CV) and chronoamperometry have been carried out by a computer controlled EG \& G PAR potentiostat/galvanostat (Model: 273A).

$\mathrm{CV}$ of each electrocatalyst was recorded in $0.5 \mathrm{M} \mathrm{H}_{2} \mathrm{SO}_{4}$ with and without containing $1.0 \mathrm{M} \mathrm{CH}_{3} \mathrm{OH}$ at $25^{\circ} \mathrm{C}$. Before recording the final voltammogram, each electrode was cycled for five runs at a scan rate of $50 \mathrm{mV} \mathrm{s}^{-1}$ in the electrolyte. All electrochemical experiments were performed in an $\mathrm{Ar}$ deoxygenated electrolyte at $25^{\circ} \mathrm{C}$. The mass of the catalytic films on GC was $0.2-0.3 \mathrm{mg} \mathrm{cm}^{-2}$ and the geometrical area of each catalyst electrode was close to 0.5 (i.e., $0.48-0.52) \mathrm{cm}^{2}$.

\section{RESULTS AND DISCUSSION}

\subsection{X-Ray Diffraction}

The X-ray diffraction (XRD) patterns of three representative electrodes, $\mathrm{Pt} / \mathrm{GC}$ (A), Pt-40wt\%MWCNT/GC (B) and Pt-40wt\%NC/GC (C) are shown in Fig. (1). The XRD pattern of pure $\mathrm{Pt}$ exhibits the face centered cubic crystal structure and the characteristic diffraction peaks corresponding to planes: (111), (200) and (220) are at Bragg angles: $2 \theta=39.6,46.07,67.28^{\circ}$, respectively (JCPDS 040802). Composites, $\mathrm{Pt}-40 \mathrm{wt} \% \mathrm{MWCNT}$ and $\mathrm{Pt}-40 \mathrm{wt} \% \mathrm{NC}$ also displayed similar diffraction patterns as found to that for pure Pt (Fig. 1) further shows that Pt exists in the pure metallic phase. The intense Pt (111) diffraction peak was

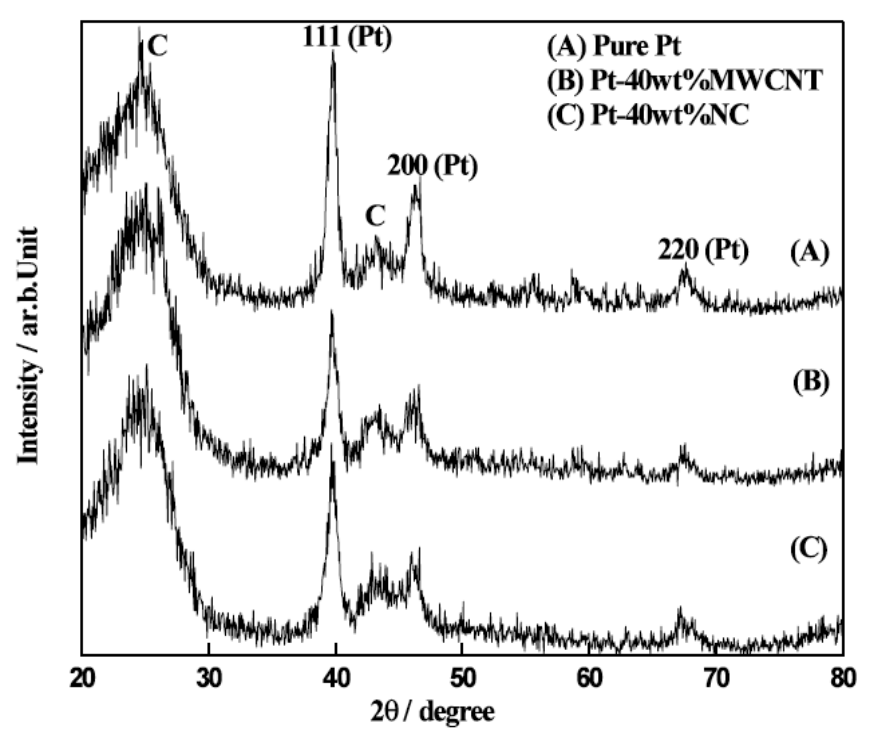

Fig. (1). XRD patterns of Pure Pt (A), Pt $-40 w t \% M W C N T$ (B) and $\mathrm{Pt}-40 \mathrm{wt} \% \mathrm{NC}(\mathrm{C})$ as deposited on GC. 
used to calculate the crystallite size according to Scherrer formula and was found to be 10.9, 10.5 and $9.9 \mathrm{~nm}$ for pure $\mathrm{Pt}, \mathrm{Pt}-40 \mathrm{wt} \% \mathrm{MWCNT}$ and $\mathrm{Pt}-40 \mathrm{wt} \% \mathrm{NC}$, respectively. Thus, crystallite size of $\mathrm{Pt}$ does not seem to change practically with the addition of $40 \mathrm{wt} \%$ MWCNT (or NC). However, this result does not support the findings of Umeda et al. [17], Hall et al. [2] and Liang et al. [1]. That the Pt particle size increases with increasing metal ion loading.

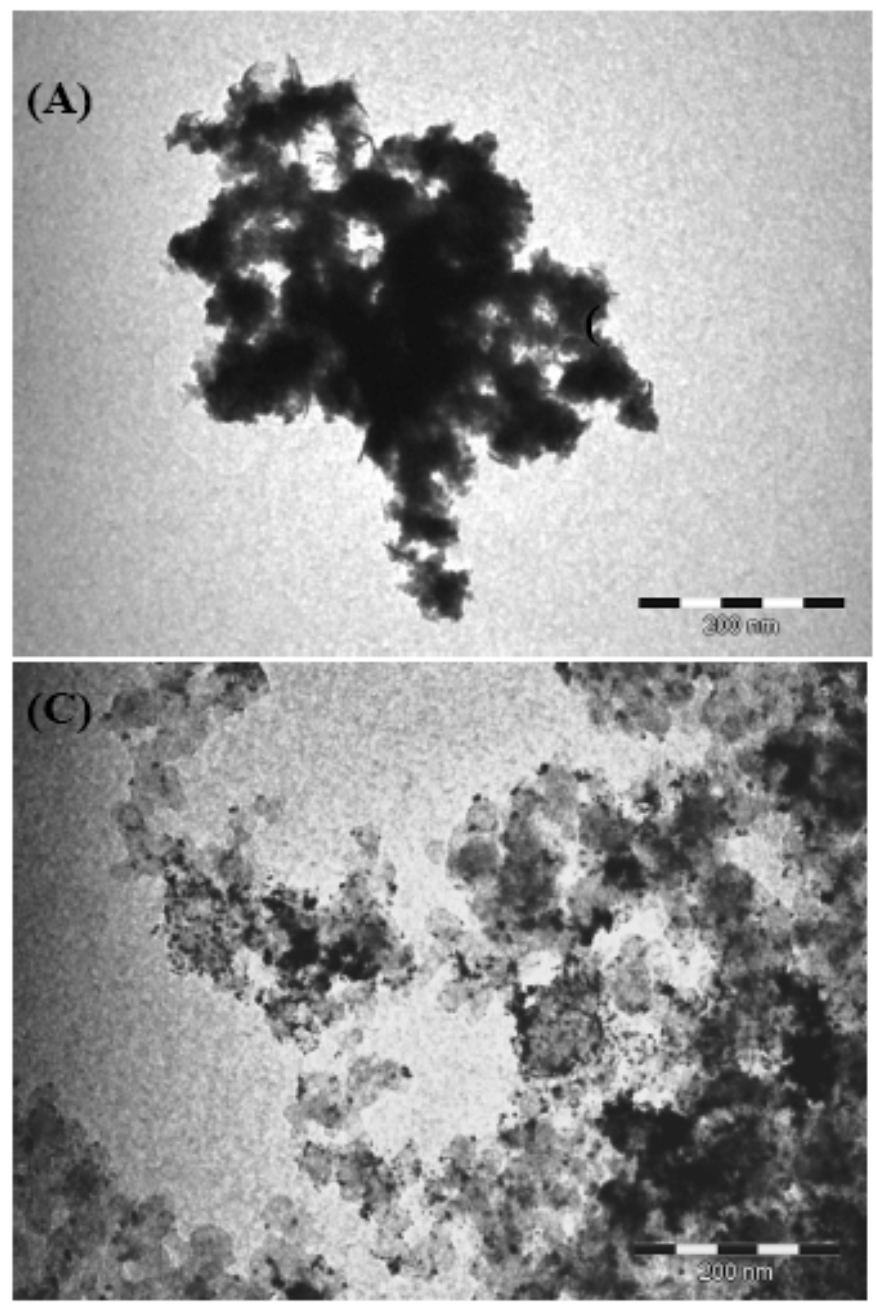

\subsection{TEM}

TEM images of some representative samples are shown in Fig. (2). Fig. (2A) is the micrograph of pure Pt. This shows that $\mathrm{Pt}$ crystallites agglomerate to produce a cluster type network. In micrograph of the composite with $20 \mathrm{wt} \%$ $\mathrm{NC}$, as shown in Fig. (2B), Pt nano-particles, nearly spherical in shape are found to disperse uniformly at the surface of carbon matrix. In the case of $80 \mathrm{wt} \% \mathrm{NC}$ also, the
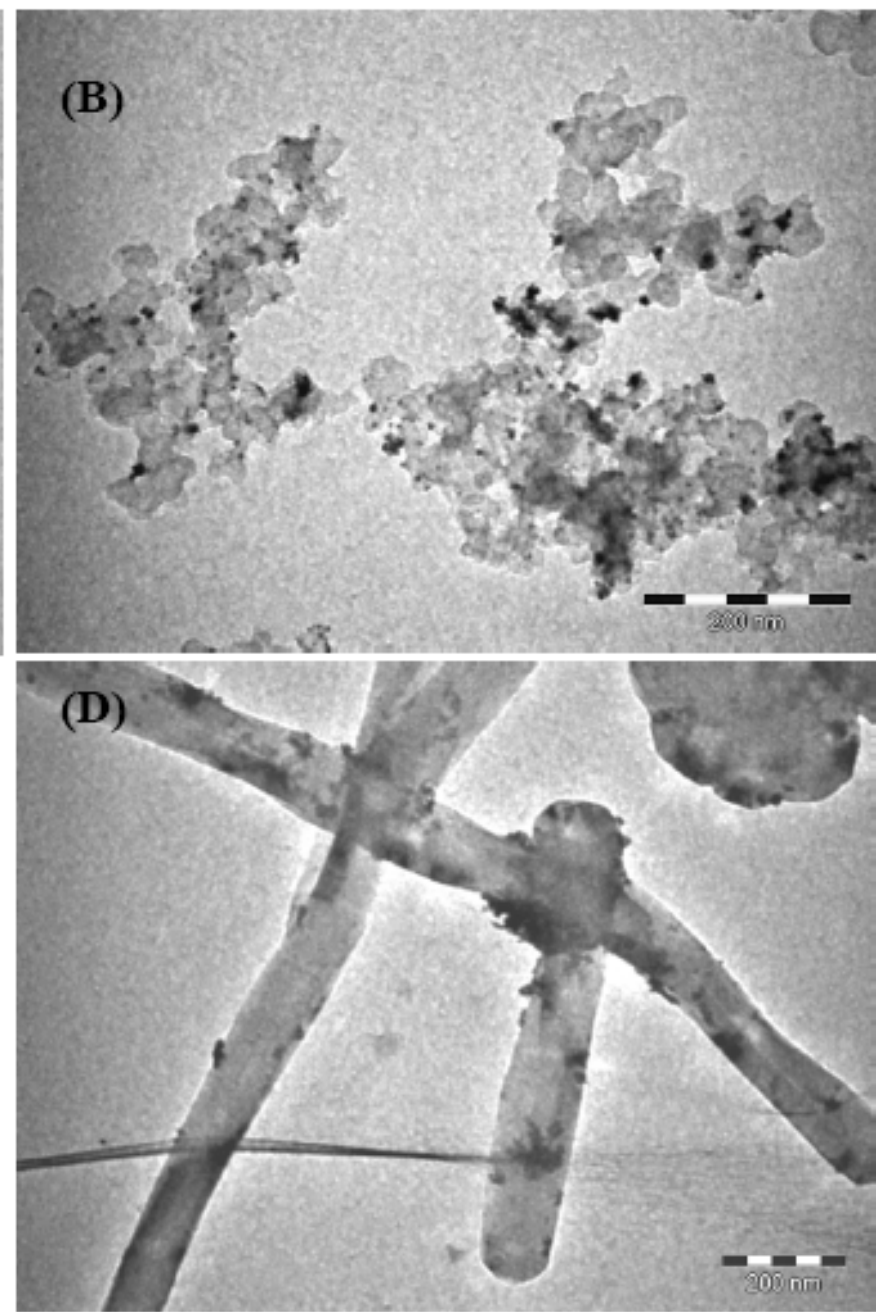

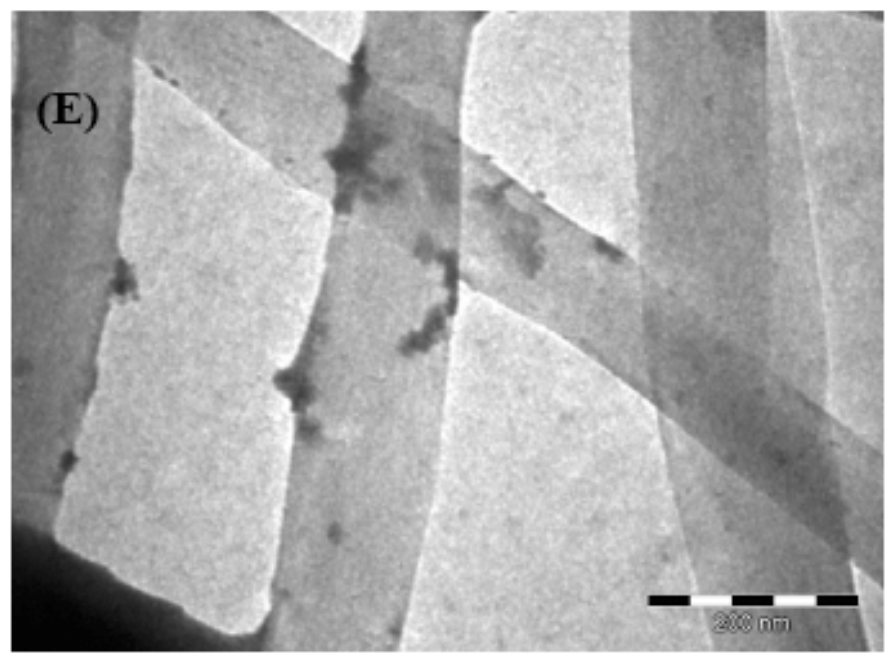

Fig. (2). TEM pictures of pure Pt (A), Pt-20wt\%NC (B), Pt-80wt\%NC (C), Pt-80wt\%MWCNT (D) and Pt-40wt\%MWCNT (E). 
dispersion of Pt nano-particles looks to be more or less uniform at the NC surface (Fig. 2C). Fig. (2D, E) are the micrographs of Pt/MWCNT catalysts wherein Pt particles are found to disperse on the surface of the MWCNTs nonhomogeneously. The presence of high density of Pt particles at some regions on the MWCNT surface might be caused due to the presence of some functional groups, mainly hydroxyl, carboxylic acid and carbonyl produced by the oxidation of the MWCNT surface.

\subsection{AFM}

The AFM images of two catalysts, Pt-20wt\%NC and Pt$80 \mathrm{wt} \% \mathrm{NC}$ shown in Fig. $(\mathbf{3 A}, \mathbf{B})$ show that the powders are in agglomerated fashion on the surface of mica. The size of

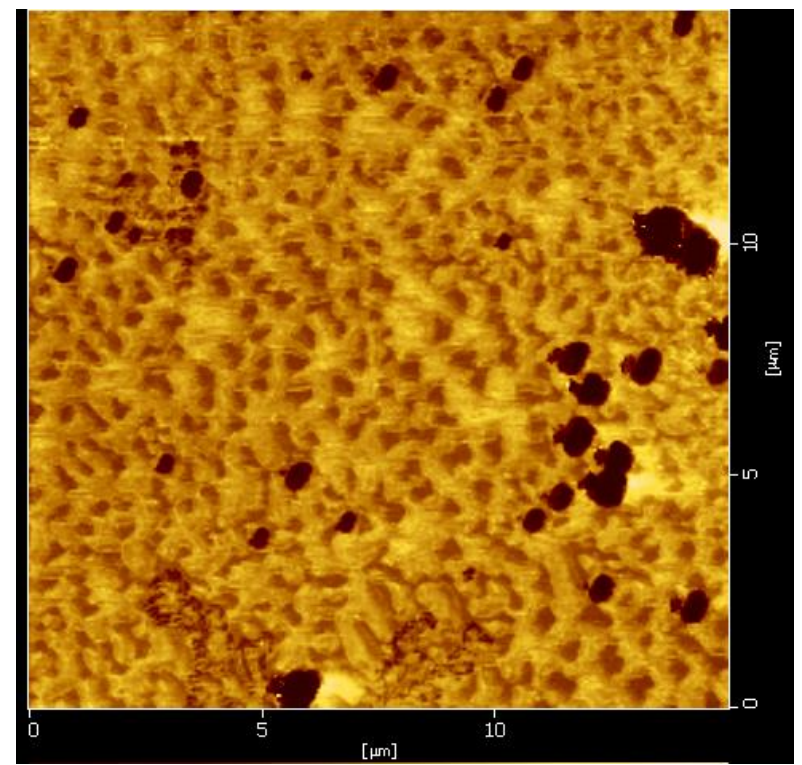

(A)

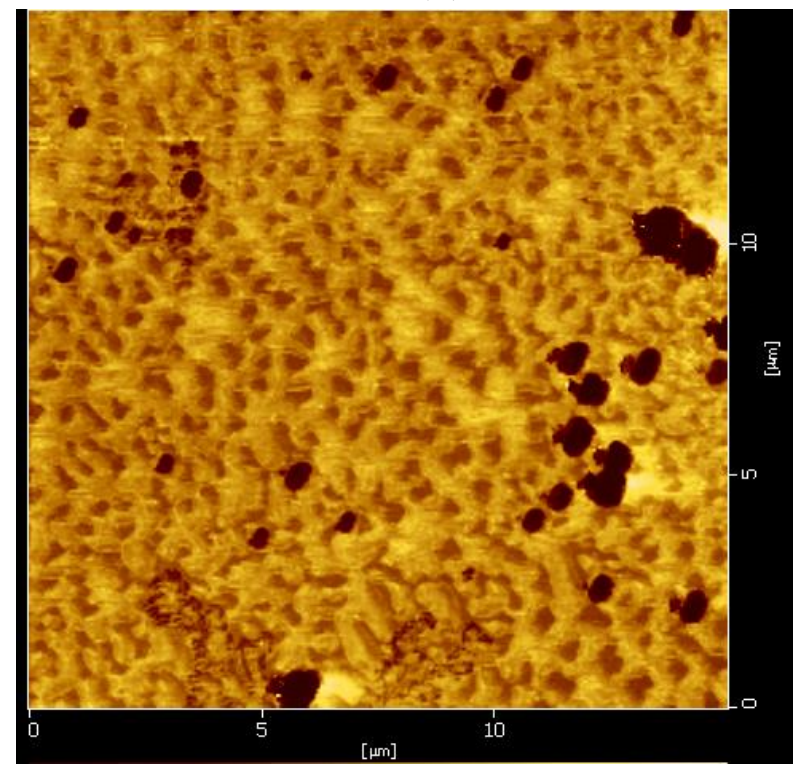

(B)

Fig. (3). AFM images of Pt-20wt $\% \mathrm{NC}(\mathbf{A})$ and $\mathrm{Pt}-80 \mathrm{wt} \% \mathrm{NC}(\mathbf{B})$. the nanoparticles is of the order of $18-36 \mathrm{~nm}$ for the sample Pt-20wt\%NC and $12-20 \mathrm{~nm}$ for Pt- $80 \mathrm{wt} \% \mathrm{NC}$. The particle sizes calculated from AFM study are somewhat higher as found by XRD.

\subsection{Cyclic Voltammetry (CV)}

CVs of Pt/GC and composite (20,30, 40, 60 and $80 \mathrm{wt} \% \mathrm{NC}$ (or MWCNT)) electrodes were recorded at a scan rate of $50 \mathrm{mV} \mathrm{s}^{-1}$ at $25^{\circ} \mathrm{C}$ and curves, so obtained, are reproduced in Figs. $(\mathbf{4}, \mathbf{5})$. The electrolytes used were $0.5 \mathrm{M}$ $\mathrm{H}_{2} \mathrm{SO}_{4}$ and $1 \mathrm{M} \mathrm{CH}_{3} \mathrm{OH}+0.5 \mathrm{M} \mathrm{H}_{2} \mathrm{SO}_{4}$. Fig. (4) shows $\mathrm{CV}$ curves for $\mathrm{Pt} / \mathrm{GC}$ and three representative composite electrodes containing 20, 40 and $60 \mathrm{wt} \% \mathrm{NC}$ (or MWCNT) in $0.5 \mathrm{M} \mathrm{H}_{2} \mathrm{SO}_{4}$ (without containing methanol) in the potential range of -0.3 to $+1.3 \mathrm{~V}$. Features of $\mathrm{CV}$ curves recorded for composites of $\mathrm{Pt}$ and $\mathrm{NC}$ (or MWCNT) in $0.5 \mathrm{M} \mathrm{H}_{2} \mathrm{SO}_{4}$ were found to be almost similar; only three representative curves for composite electrodes are shown in Fig. (4). These $\mathrm{CV}$ curves demonstrate two cathodic and two to three anodic peaks between $-0.3 \mathrm{~V}$ and $+0.1 \mathrm{~V}$. These are characteristic peaks for the adsorption and desorption of Hydrogen atom [17]. The three anodic peaks were also observed by Kinoshita et al. [21] in the case of $\mathrm{Pt} / \mathrm{C}$ electrodes (Pt: 10$50 \mathrm{wt} \%)$. The difference in the CV Profile can be ascribed to a change in the surface crystallinity. The strong cathodic peak at $\mathrm{E}=\sim 0.4 \mathrm{~V}$ is produced due to reduction of $\mathrm{Pt}$ (II) into Pt (0). A broad anodic peak observed in the potential range, $0.6 \mathrm{~V}-0.9 \mathrm{~V}$, well before the oxygen evolution peak $(1.2-1.3 \mathrm{~V})$, corresponds to the oxidation of Pt metal into PtO.

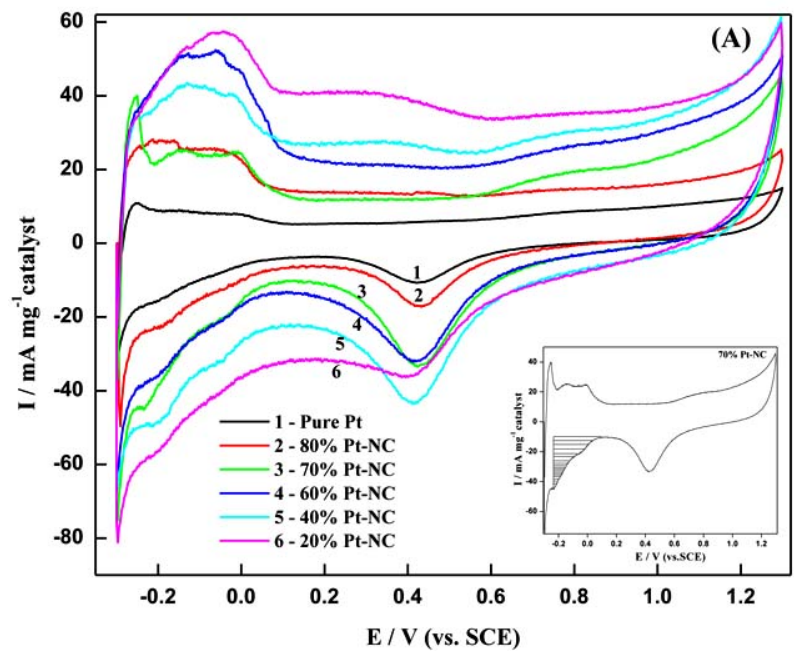

Fig. (4A). Cyclic voltammograms of Pure-Pt, Pt-20wt $\%$ NC, Pt$40 \mathrm{wt} \% \mathrm{NC}$ and $\mathrm{Pt}-60 \mathrm{wt} \% \mathrm{NC}$ composites at a scan rate of $50 \mathrm{mVs}^{-1}$ in $0.5 \mathrm{M} \mathrm{H}_{2} \mathrm{SO}_{4}$. The curve shown in 'inset' of Fig. (A) is the voltammogram for the electrode, $\mathrm{Pt}-30 \mathrm{wt} \% \mathrm{NC}$.

Fig. (5) demonstrates the cyclic voltammograms for pure $\mathrm{Pt}$ and composite electrodes in $0.5 \mathrm{M} \mathrm{H}_{2} \mathrm{SO}_{4}+1 \mathrm{M} \mathrm{CH}_{3} \mathrm{OH}$ in the potential range from 0.0 to $+1.0 \mathrm{~V}$. CV curves for each composite electrode were more or less similar and so, for clarity in representation, only three representative voltammograms for either kind of composite electrodes are given in Fig. (5). This figure displays two well defined 


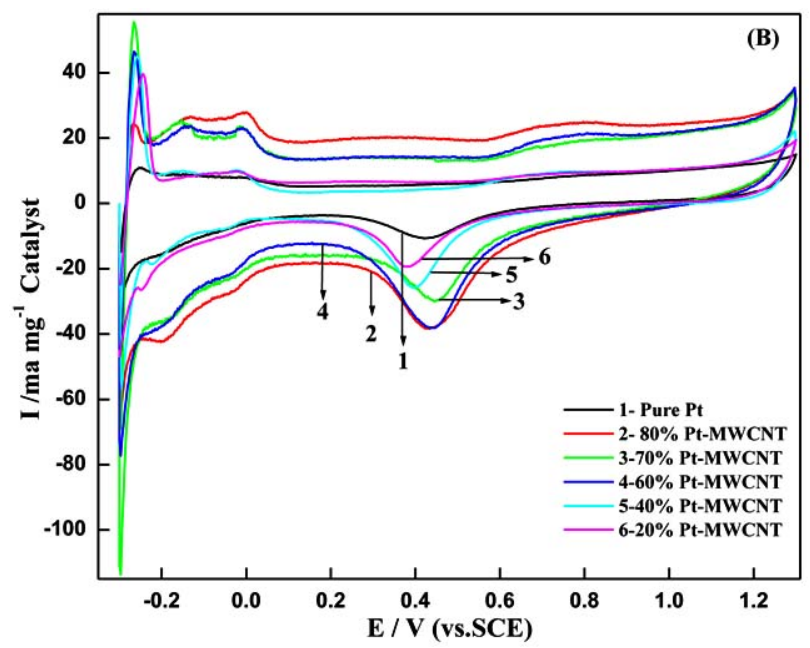

Fig. (4B). Cyclic voltammograms of Pure-Pt, Pt-20wt\%MWCNT, Pt-40wt\%MWCNT and Pt-60wt\% MWCNT composites at a scan rate of $50 \mathrm{mVs}^{-1}$ in $0.5 \mathrm{M} \mathrm{H}_{2} \mathrm{SO}_{4}$.

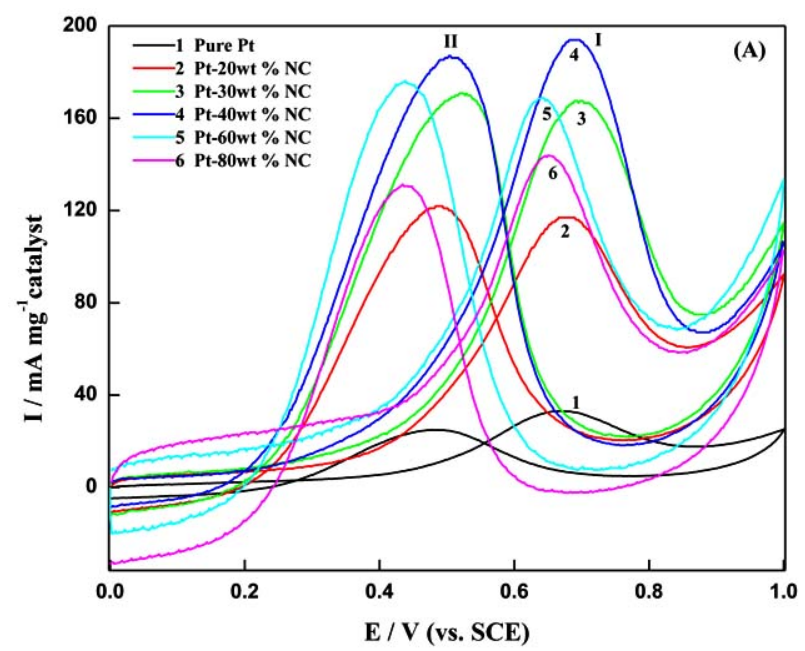

Fig. (5A). Cyclic voltammograms of Pure-Pt, Pt-20wt $\%$ NC, Pt$40 \mathrm{wt} \% \mathrm{NC}$ and Pt-60wt $\% \mathrm{NC}$ composites at a scan rate of $50 \mathrm{mVs}^{-1}$ in $0.5 \mathrm{M} \mathrm{H}_{2} \mathrm{SO}_{4}+1 \mathrm{M} \mathrm{CH}_{3} \mathrm{OH}$.

anodic current peaks, one in the forward (I) (i.e. under anodic condition) and the other one (II) in the reverse (i.e. under cathodic condition) scan. The oxidation current peak (I) is produced due to the oxidation of freshly chemisorbed species coming from methanol adsorption. The oxidation peak (II) is primarily associated with the removal of carbonaceous species not completely oxidized in the forward scan, rather than caused by freshly chemisorbed species [2224]. Further, the height of the forward peak current as well as the reverse peak current in the case of each composite electrode is more or less the same. CV curves determined in $0.5 \mathrm{M} \mathrm{H}_{2} \mathrm{SO}_{4}+1 \mathrm{M} \mathrm{CH} \mathrm{CH}_{3} \mathrm{OH}$ (Fig. 5) were analyzed for the onset potential $\left(\mathrm{E}_{\mathrm{op}}\right)$, peak current $\left(\mathrm{I}_{\mathrm{p}}\right)$ and peak potential $\left(\mathrm{E}_{\mathrm{p}}\right)$ and their values are listed in Table $\mathbf{1}$.

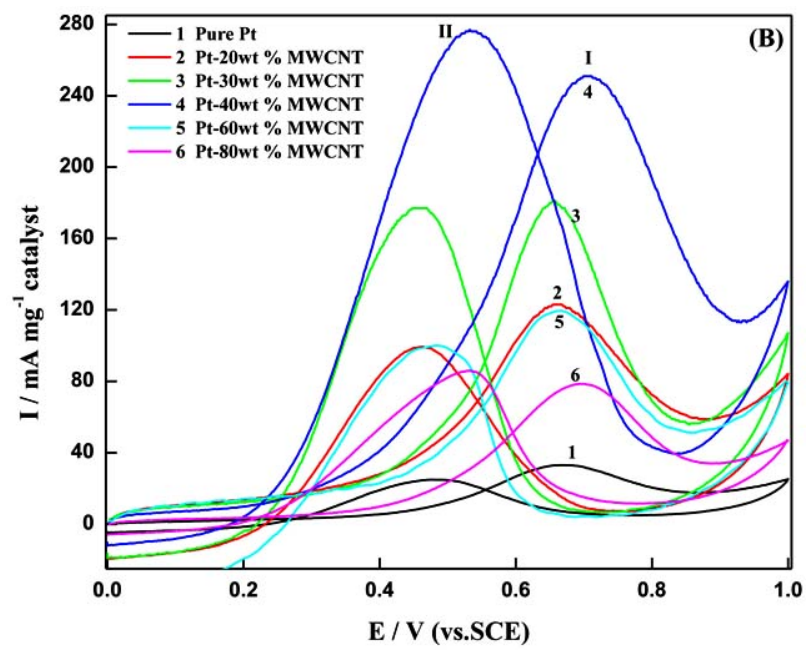

Fig. (5B). Cyclic voltammograms of Pure-Pt, Pt-20wt\%MWCNT, Pt-40wt\%MWCNT and Pt-60wt\% MWCNT composites at a scan rate of $50 \mathrm{mVs}^{-1}$ in $0.5 \mathrm{M} \mathrm{H}_{2} \mathrm{SO}_{4}+1 \mathrm{M} \mathrm{CH}_{3} \mathrm{OH}$.

Table 1 shows that the composite electrodes have greatly enhanced electro-catalytic activities compared to that of pure Pt. Further, an increase in percentage of NC from 20 to $80 \mathrm{wt} \%$, the observed methanol oxidation peak current (Ip) in the forward scan increases, reaches a maximum at $40 \mathrm{wt} \%$ addition of $\mathrm{NC}$ and declines thereafter. Similar effect of addition of MWCNT was also observed (Table 2). However, the observed peak current normalized with respect to the amount of $\mathrm{Pt}$ (per $\mathrm{mg}$ of $\mathrm{Pt}$ ) in the composite increases continuously with increasing addition of NC from 20 to $80 \mathrm{wt} \%$. On the other hand, in the case of MWCNT-Pt composites, with introduction of the MWCNT, the peak

Table1. Results of Cyclic Voltammetry of Methanol Electro-Oxidation at Pt-NC Composite Electrodes in $\mathrm{O.}_{2} \mathrm{M}_{\mathbf{2}} \mathrm{SO}_{4}+1 \mathrm{M}$ $\mathrm{CH}_{3} \mathrm{OH}$ at $50 \mathrm{mV} \mathrm{s}^{-1}$ and at $25^{\circ} \mathrm{C}$

\begin{tabular}{|c|c|c|c|c|c|c|c|}
\hline \multirow{2}{*}{ Electrode wt $\%$ Pt } & \multicolumn{2}{|c|}{ Loading ( $\mathrm{mg} \mathrm{cm}^{-2}$, Geometrical) } & \multirow{2}{*}{$\mathbf{E}_{\text {op }} \mathbf{m V}$} & \multicolumn{3}{|c|}{ Oxidation Peak Current $I_{p}(I)$ Observed } & \multirow{2}{*}{$\mathbf{E}_{\mathrm{p}} / \mathbf{m V}$} \\
\hline & Catalyst & $\mathbf{P t}$ & & $\mathbf{m A}$ & mAmg $^{-1}$ Catalyst & $\mathrm{mAmg}^{-1} \mathrm{Pt}$ & \\
\hline 100 & 0.29 & 0.29 & 304 & 5 & 32 & 32 & 672 \\
\hline 80 & $0.28 \pm 0.01$ & $0.23 \pm 0.01$ & $268 \pm 7$ & $17 \pm 2$ & $120 \pm 14$ & $157 \pm 15$ & $678 \pm 2$ \\
\hline 70 & $0.28 \pm 0.02$ & $0.20 \pm 0.02$ & $261 \pm 8$ & $21 \pm 1$ & $149 \pm 18$ & $251 \pm 11$ & $701 \pm 0$ \\
\hline 60 & $0.27 \pm 0.02$ & $0.17 \pm 0.02$ & $253 \pm 18$ & $24 \pm 2$ & $181 \pm 26$ & $347 \pm 35$ & $683 \pm 7$ \\
\hline 40 & $0.22 \pm 0.01$ & $0.06 \pm 0.00$ & $255 \pm 24$ & $17 \pm 1$ & $157 \pm 12$ & $587 \pm 4$ & $661 \pm 21$ \\
\hline 20 & $0.20 \pm 0.01$ & $0.04 \pm 0.02$ & $407 \pm 2$ & $14 \pm 6$ & $138 \pm 4$ & $720 \pm 8$ & $719 \pm 6$ \\
\hline
\end{tabular}


Table 2. Results of Cyclic Voltammetry of Methanol Electro-Oxidation at Pt-MWCNT Composite Electrodes in $0.5 \mathrm{M}_{2} \mathrm{SO}_{4}+$ $1 \mathrm{M} \mathrm{CH} \mathrm{CH}_{3} \mathrm{OH} 50 \mathrm{mV} \mathrm{s}^{-1}$ and at $25^{\circ} \mathrm{C}$

\begin{tabular}{|c|c|c|c|c|c|c|c|}
\hline \multirow{2}{*}{ Electrode wt\% Pt } & \multicolumn{2}{|c|}{ Loading (mgcm ${ }^{-2}$, Geometrical) } & \multirow{2}{*}{$\mathbf{E}_{\mathrm{op} /} \mathbf{m V}$} & \multicolumn{3}{|c|}{ Oxidation Peak Current $I_{p}(I)$ Observed } & \multirow{2}{*}{$\mathbf{E}_{\mathbf{p}} / \mathbf{m V}$} \\
\hline & Catalyst & $\mathbf{P t}$ & & $\mathbf{m A}$ & mAmg $^{-1}$ Catalyst & $\mathrm{mAmg}^{-1} \mathrm{Pt}$ & \\
\hline 100 & 0.29 & 0.29 & 304 & 5 & 32 & 32 & 672 \\
\hline 80 & $0.38 \pm 0.02$ & $0.30 \pm 0.02$ & $290 \pm 4$ & $23 \pm 8$ & $123 \pm 4$ & $155 \pm 10$ & $662 \pm 6$ \\
\hline 70 & $0.28 \pm 0.02$ & $0.20 \pm 0.02$ & $258 \pm 22$ & $22 \pm 1$ & $158 \pm 22$ & $238 \pm 23$ & $657 \pm 3$ \\
\hline 60 & $0.26 \pm 0.02$ & $0.15 \pm 0.01$ & $261 \pm 2$ & $26 \pm 3$ & $208 \pm 33$ & $399 \pm 31$ & $712 \pm 7$ \\
\hline 40 & $0.29 \pm 0.00$ & $0.08 \pm 0.00$ & $308 \pm 15$ & $18 \pm 1$ & $123 \pm 6$ & $440 \pm 7$ & $668 \pm 0$ \\
\hline 20 & $0.23 \pm 0.02$ & $0.05 \pm 0.00$ & $325 \pm 28$ & $8 \pm 1$ & $74 \pm 2$ & $423 \pm 46$ & $697 \pm 1$ \\
\hline
\end{tabular}

current per mg of $\mathrm{Pt}$ increases up to $40 \mathrm{wt} \%$ and becomes nearly constant thereafter.

The catalytic activity of an electrode material is known to depend upon the geometrical as well as the electronic properties of the material. In order to know the effect of introduction of carbon on the electronic properties of the catalyst, the knowledge of the electrochemical active surface area (EASA) of the each electrode is required. As described elsewhere [25], the EASA of the electrodes has been estimated by determining the coulombic charge $\left(\mathrm{Q}_{\mathrm{H}}\right)$ required for the electrochemical adsorption of hydrogen atom on $\mathrm{Pt}$. For the purpose, the two cathodic peaks observed between -0.3 and $+0.10 \mathrm{~V}$, which correspond to the electro-adsorption of the hydrogen atom on to the metallic Pt surface, have been employed for the estimation of EASA using the relation $[26,27]$,

$$
E A S A=\frac{Q_{H}}{Q_{H, r e f}}
$$

where $\mathrm{Q}_{\mathrm{H}}$ is the amount of charge exchanged during the electro-sorption of hydrogen atoms onto the $\mathrm{Pt}$ surface and $\mathrm{Q}_{\mathrm{H}, \mathrm{ref}}$ is considered to be $0.21 \mathrm{mC} \mathrm{cm}^{-2}$ in case of Pt. This value corresponds to a surface density of $1.3 \times 10^{15}$ atom $/ \mathrm{cm}^{2}$, a generally accepted value for polycrystalline $\mathrm{Pt}$ electrode [28]. $\mathrm{Q}_{\mathrm{H}}$ was determined by integrating the area under the cathodic curves observed between -0.3 and $+0.10 \mathrm{~V}$ (as shown by shaded area in inset of Fig. 4A) through an integrator facility provided in the instrument (potentiostat/ galvanostat). Estimates of EASA of electrodes are shown in Tables 3 and $\mathbf{4}$.

Results shown in Tables 3 and 4, show that the EASA increases with the introduction of NC/ MWCNT from 20 to $80 \mathrm{wt} \%$ into $\mathrm{Pt}$ mass. The increase in the EASA can be attributed to a better dispersion of $\mathrm{Pt}$ and also to the decrease in the Pt particle size [2, 17], on increasing the percentage of $\mathrm{NC} / \mathrm{MWCNT}$ in the composite.

To compare the electro-catalytic activities of composite electrodes, values of the observed apparent current were noted at a constant common potential, $\mathrm{E}=630.7 \mathrm{mV}$, prior to the oxidation current peak on the forward scan (Fig. $\mathbf{5 A}$, B) and are given in Tables $\mathbf{3}$ and 4. To determine the influence of introduction of NC/MWCNT on the electronic properties or specific activity, SA $\left(=\mathrm{I}, \mathrm{mA} \mathrm{mg}^{-1} \mathrm{Pt} / \mathrm{EASA}\right.$, $\mathrm{cm}^{2} \mathrm{mg}^{-1} \mathrm{Pt}$ ) of the material, the apparent currents, I (observed), were normalized with respect to the EASA and values, so obtained, are given in Tables 3 and 4. The data shown in Tables indicate that with an exception to $80 \mathrm{wt} \%$ MWCNT addition, SA-values of all the composite electrodes, regardless of their composition as well as nature, are practically the same, but they are significantly higher than that obtained for pure Pt. Thus, the results show that both the geometrical as well as electronic properties of dispersed $\mathrm{Pt}$ on carbon get improved considerably. Further, there is no significance difference in the specific activities of NC-Pt and of MWCNT-Pt composites with regard to MOR. Thus, the result indicates that the use of MWCNTs, in place of a low cost nano-carbon powder, as support is not beneficial from electrocatalysis standpoint.

Table 3. Estimates of EASA and Specific Activity (SA) of Pt-NC Composite Electrodes Towards Methanol Electro-Oxidation in $0.5 \mathrm{M} \mathrm{H}_{2} \mathrm{SO}_{4}+1 \mathrm{M} \mathrm{CH}_{3} \mathrm{OH}$ at $50 \mathrm{mV} \mathrm{s}^{-1}$ and at $25^{\circ} \mathrm{C}$

\begin{tabular}{|c|c|c|c|c|c|c|c|}
\hline \multirow{2}{*}{ Electrode wt\% Pt } & \multicolumn{2}{|c|}{ Loading $\left(\mathrm{mgcm}^{-2}\right.$, Geometrical) } & \multicolumn{2}{|c|}{$Q_{H}\left(m C g^{-1}\right)$} & \multirow{2}{*}{$\underset{\left(\mathrm{cm}^{2} \mathrm{mg}^{-1} \mathrm{Pt}\right)}{\text { EASA }}$} & \multirow{2}{*}{$\begin{array}{r}\text { I }\left(\mathrm{mAmg}^{-1} \mathrm{Pt}\right) \\
\text { at } \mathrm{E}=630.7 \mathrm{mV}\end{array}$} & \multirow{2}{*}{$\mathrm{SA}\left(=\underset{(\mathrm{mAcm})}{\left.\mathbf{I}, \mathrm{mA} \mathrm{mg}^{1} \mathbf{P t} / \mathrm{EASA}\right)}\right.$} \\
\hline & Catalyst & Pt & Catalyst & Pt & & & \\
\hline 100 & 0.29 & 0.29 & 28 & 28 & 135 & 31 & 0.23 \\
\hline 80 & $0.28 \pm 0.01$ & $0.23 \pm 0.01$ & $37 \pm 1$ & $47 \pm 0$ & $222 \pm 2$ & $139 \pm 14$ & $0.65 \pm 0.1$ \\
\hline 70 & $0.28 \pm 0.02$ & $0.20 \pm 0.02$ & $71 \pm 4$ & $102 \pm 5$ & $484 \pm 24$ & $196 \pm 13$ & $0.42 \pm 0$ \\
\hline 20 & $0.20 \pm 0.01$ & $0.04 \pm 0.02$ & $81 \pm 1$ & $407 \pm 1$ & $1939 \pm 4$ & $708 \pm 2$ & $0.52 \pm 0.1$ \\
\hline
\end{tabular}


Table 4. Estimates of the EASA and Specific Activity (SA) of Pt-MWCNT Composite Electrode Towards Methanol ElectroOxidation in $0.5 \mathrm{M} \mathrm{H}_{2} \mathrm{SO}_{4}+1 \mathrm{M} \mathrm{CH}_{3} \mathrm{OH}$ at $50 \mathrm{mV} \mathrm{s}^{-1}$ and at $25^{\circ} \mathrm{C}$

\begin{tabular}{|c|c|c|c|c|c|c|c|}
\hline \multirow{2}{*}{ Electrode wt\% Pt } & \multicolumn{2}{|c|}{ Loading $\left(\mathrm{mgcm}^{-2}\right.$, Geometrical) } & \multicolumn{2}{|c|}{$\mathrm{Q}_{\mathrm{H}}\left(\mathrm{mC} \mathrm{mg}^{-1}\right)$} & \multirow{2}{*}{$\begin{array}{c}\text { EASA } \\
\left(\mathrm{cm}^{2} \mathrm{mg}^{-1} \mathbf{P t}\right)\end{array}$} & \multirow{2}{*}{$\begin{array}{l}\text { I }\left(\mathrm{mAmg}{ }^{-1} \mathrm{Pt}\right) \\
\text { atE }=630.7 \mathrm{mV}\end{array}$} & \multirow{2}{*}{$\mathrm{SA}\left(=\underset{\left(\mathrm{mAcm}^{-2}\right)}{\mathrm{I}, \underset{\mathrm{mA} \mathrm{mg}}{\mathbf{m}} \mathbf{P t} / \mathrm{EASA})}\right.$} \\
\hline & Catalyst & Pt & Catalyst & Pt & & & \\
\hline 100 & 0.29 & 0.29 & 28 & 28 & 135 & 31 & 0.23 \\
\hline 80 & $0.38 \pm 0.02$ & $0.30 \pm 0.02$ & $55 \pm 3$ & $70 \pm 1$ & $334 \pm 8$ & $149 \pm 9$ & $0.45 \pm 0.0$ \\
\hline 70 & $0.28 \pm 0.02$ & $0.20 \pm 0.02$ & $51 \pm 1$ & $73 \pm 1$ & $346 \pm 6$ & $228 \pm 14$ & $0.66 \pm 0.1$ \\
\hline 60 & $0.26 \pm 0.02$ & $0.15 \pm 0.01$ & $62 \pm 1$ & $106 \pm 1$ & $506 \pm 5$ & $322 \pm 17$ & $0.64 \pm 0.1$ \\
\hline 40 & $0.29 \pm 0.00$ & $0.08 \pm 0.00$ & $37 \pm 5$ & $135 \pm 19$ & $687 \pm 46$ & $374 \pm 23$ & $0.66 \pm 0.1$ \\
\hline 20 & $0.23 \pm 0.02$ & $0.05 \pm 0.00$ & $74 \pm 1$ & $370 \pm 20$ & $1761 \pm 41$ & $362 \pm 20$ & $0.24 \pm 0.0$ \\
\hline
\end{tabular}

\subsection{Chronoamperometry}

Chronoamperograms recorded at $\mathrm{E}=0.6 \mathrm{~V}$ for pure $\mathrm{Pt}$, Pt-80wt\%NC, Pt-40wt\%NC, Pt-80wt\% MWCNT and Pt$40 \mathrm{wt} \% \mathrm{MWCNT}$ electrodes in $0.5 \mathrm{M} \mathrm{H}_{2} \mathrm{SO}_{4}+1 \mathrm{M} \mathrm{CH}_{3} \mathrm{OH}$ for $2 \mathrm{~h}$, are shown in Fig. (6). This figure shows that all the electrodes get poisoned during electrolysis, however, the magnitude of the poisoning effect is found to be quite low in the case of $\mathrm{Pt}-80 \mathrm{wt} \% \mathrm{MWCNT}$ and $\mathrm{Pt}-40 \mathrm{wt} \% \mathrm{NC}$ electrodes. Thus, the electrodes, Pt-80wt\%MWCNT and Pt-40wt\%NC, exhibit much better electrochemical performance as well as poisoning tolerance than the other electrodes of the investigation.

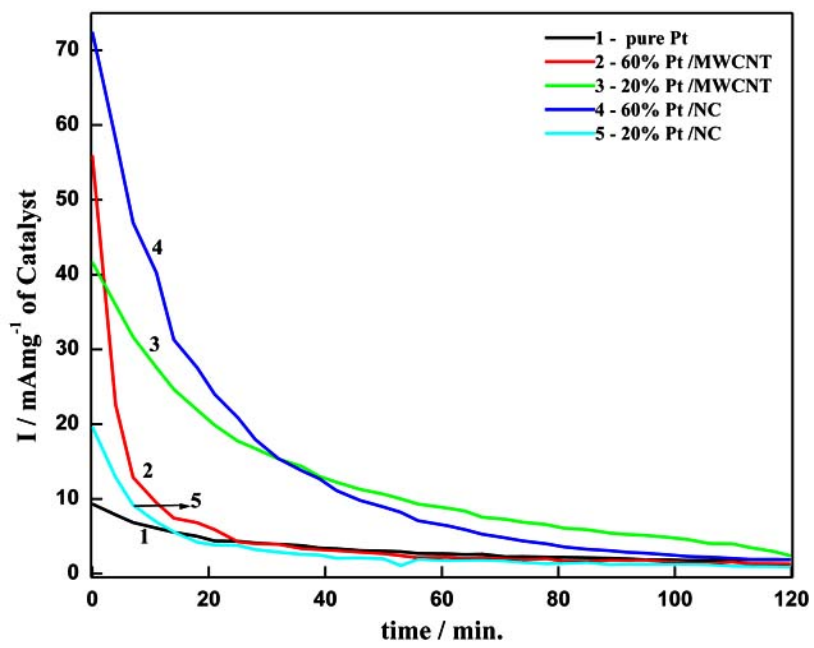

Fig. (6). Stability curves for different electrocatalysts in $0.5 \mathrm{M}$ $\mathrm{H}_{2} \mathrm{SO}_{4}+1 \mathrm{M} \mathrm{CH}_{3} \mathrm{OH}$ at $\mathrm{E}=0.6 \mathrm{~V}$.

\section{CONCLUSIONS}

The study demonstrates that both nano-carbon and MWCNTs behave in almost similar manner as support materials for Pt catalyst and that the specific activities of the composite materials, regardless of Pt content and the nature of the support material are found to be practically the same, independently of Pt content and the nature of the support. Among the composite electrocatalysts investigated in $0.5 \mathrm{M}$ $\mathrm{H}_{2} \mathrm{SO}_{4}+1.0 \mathrm{M} \mathrm{CH}{ }_{3} \mathrm{OH}$ at $25^{\circ} \mathrm{C}$, the $\mathrm{Pt}-40 \mathrm{wt} \% \mathrm{NC}$ (or MWCNT) electrode exhibited the greatest apparent electrocatalytic activity ( $\mathrm{mA} / \mathrm{mg}$ of catalyst). However, the poisoning tolerance of the $\mathrm{Pt}-80 \mathrm{wt} \% \mathrm{MWCNT}$ electrode against methanol oxidation intermediates was somewhat superior to the former electrode $(\mathrm{Pt}-40 \mathrm{wt} \% \mathrm{NC})$ under similar experimental conditions.

\section{ACKNOWLEDGEMENTS}

One of authors (RA) thanks the Council of Scientific and Industrial Research (CSIR) New Delhi for the award of Fellowship. Authors also thank the Department of Science and Technology, Government of India for financial support through a research project (SR/S1/PC-41) and the Director, Institute of Medical Sciences, Banaras Hindu University for allowing to use electron microscope facility.

\section{REFERENCES}

[1] Liang, Y.; Li, J.; Xu, Q-C.; Hu, R.-Z.; Lin, J.-D.; Liao, D.-W Characterization of composite carbon supported PtRu catalyst and its catalytic performance for methanol oxidation. J Alloys comp., 2008, 465, 296-304.

[2] Hall, S.C.; Subramanian, V.; Teeter, G.; Rambabu, B. Influence of metal-support interaction in $\mathrm{Pt} / \mathrm{C}$ on $\mathrm{CO}$ and methanol oxidation reactions. Solid State Ionics., 2004, 175, 809-813.

[3] Antolini, E. Formation of Carbon-Supported Pt Ni alloys for low temperature fuel cells: a review. Mat. Chem. Phys., 2003, 78, 563573.

[4] Tian, Z.Q.; Jiang, S.P.; Liang, Y.M.; Shen, V.J. Synthesis and characterization of Pt catalysts on multi-walled carbon nanotubes by intermittent microwave irradiation for fuel cell applications. Phys. Chem. B, 2006, 110, 5343-5350

[5] Rajesh, B.; Thampi, K.R.; Bonard, J.M.; Xanthpoulos, N.; Mathieu, H.J.; Viswanathan, B. Carbon Nanotubes Genertated from Template Carbonization of Polyphenyl Acetylene as Support for Electrooxidation of Methanol. J. Phys. Chem., 2003, 107, 27012708

[6] Gupta, S.S.; Mahapatra, S.S.; Datta, J. A potential anode material for the direct alcohol fuel cell. J. Power Sources., 2004, 131, 169174.

[7] Parsons, R.; Vandernoot, T. The Oxidation of small organic molecules: A Survey of recent fuel cell related research. $J$. Electroanal. Chem., 1988, 257, 9-45.

[8] Antolini, E. Carbon Support for low-temperature fuel cell catalysts. Appl. Catal. B Environ., 2008, 88, 1-24.

[9] Bessel, C.A.; Laubernds, K.; Rodriguez, N.M.; Baker, R.T.K. Graphite Nanofibers as an electrode for fuel cell Applications. $J$. Phys. Chem.B, 2001, 105, 1115-1118.

[10] Steigerwalt, E.S.; Deluga, G.A.; Cliffel, D.E.; Lukehart. C.M. A Pt$\mathrm{Ru} /$ graphitic carbon nanofiber nanocomposite exhibiting high relative performance as a direct-methanol fuel cell anode catalyst. J. Phys. Chem. B, 2001, 105, 8097-8101.

[11] Steigerwalt, E.S.; Deluga, G.A.; Lukehart, C.M. Pt-Ru/C fiber nanocomposites: synthesis, characterization, and performance as anode catalyst of direct methanol fuel cells. A search for exceptional performance. J. Phys. Chem. B, 2002, 106, 760-766.

[12] Alcaide, F.; Alvarez, G.; Miguel, O.; Lazaro, M.J.; Moliner, R.; Cudero, A.L.; Gullon, J.S.; Herrero, E.; Aldaz, A. Pt supported on 
carbon nanofibers as electrocatalyst for low temperature polymer electrode membrane fuel cells. Electrochem. Commun., 2009, 11, 1081-1084.

[13] Hyeon, T.; Han, S.; Sung, Y.-E.; Park, K.-W.; Kim, Y.-W. Highperformance Direct Methanol Fuel Cell Electrodes using SolidPhase-Synthesized Carbon Nanocoils. Angew. Chem. Int. Ed., 2003, 42, 4352-4356.

[14] Park, K.W.; Sung, Y.E.; Han, S.; Yun, Y.; Hyeon, T. Origin of the enhance catalytic activity of carbon nanocoil-supported PtRu alloy electrocatalysts. J. Phys. Chem. B, 2004, 108, 939-944.

[15] Frackowiak, E.; Lota, G.; Cacciaguerra, T.; Beguin, F. Carbon nanotubes with Pt-Ru catalyst for methanol fuel cell. Electrochem. Commun., 2006, 8, 129-132.

[16] Wu, W.; Zhu, Z.; Liu, Z. Metal-carbon nano-materials prepared directly from pitch. Carbon, 2002, 40, 787-803.

[17] Umeda, M.; Kokubo, M.; Mohamedi, M.; Uchida, I. Porousmicroelectrode study on $\mathrm{Pt} / \mathrm{C}$ catalysts for methanol electrooxidation. Electrochim. Acta., 2003, 48, 1367-1374.

[18] Singh, R.N.; Singh, A.; Anindita. Electrocatalytic activity of binary and ternary Composite film of Pd,MWCNT, and Ni for ethanol electro-oxidation in alkaline solutions. Carbon, 2009, 47, 271-278.

[19] Wang, J.; Xi, J.; Bai, Y.; Shen, Y.; Sun, J.; Chen, L.; Zhu, W.; Qiu. $\mathrm{X}$. Structural designing of $\mathrm{Pt}-\mathrm{CeO}_{2} / \mathrm{CNTs}$ for methanol electrooxidation. J. Power Sources, 2007, 164, 555-560.

[20] Singh, R.N.; Sharma, T.; Singh, A.; Anindita, Mishra, D.; Tiwari, S.K. Perovskite-type $\mathrm{La}_{2-\mathrm{x}} \mathrm{Sr}_{\mathrm{x}} \mathrm{NiO}_{4}(0 \leq \mathrm{x} \leq 1)$ as active anode materials for methanol oxidation in alkaline Solutions. Electrochim. Acta., 2008, 53, 2322-2330.
[21] Kinoshita, K.; Ferrier, D.R.; Stonehart, P. Synthesis of PtRu Nanoparticles from the Hydrosilylation Reaction and Application as Catalyst for Direct Methanol Fuel Cell. Electrochim. Acta, 1978, $23,45-54$.

[22] Huang, J.C.; Liu, Z.L.; He, C.B.; Gan, L.M. Synthesis of PtRu Nanoparticles from the Hydrosilylation Reaction and Application as Catalyst for Direct Methanol Fuel Cell. J. Phys. Chem. B, 2005, 109, 16644-16649.

[23] Morin, M.C.; Lamy, C.; Leger, J.M.; Vazquez, J.-.L.; Aldaz, A. Structural effects in electrocatalysis: Oxidation of ethanol on platinum single crystal electrodes.Effect of $\mathrm{pH}$. J. Electroanal. Chem., 1990, 283, 287-302.

[24] Liu, J.; Ye, J.; Xu, C.; Jiang, S.P.; Tong, Y. Kinetics of ethanol electrooxidation at $\mathrm{Pd}$ electrodeposited on Ti. Electrochem. Commun., 2007, 9, 2334-2339.

[25] Xu, B.; Guo, J.; Jia, H.; Yang, X.; Liu, X. Electrocatalytic properties of platinum on hard carbon spherules derived from deoiled asphalt for methanol oxidation. Catal. Today, 2007, 125, 169-172.

[26] Watanabe, M.; Makita, K.; Usami, H.; Motoo, S. New prepration method of a high performance gas diffusion electrode working at $100 \%$ utilization of catalyst clusters and analysis of the reaction layer. J. Electroanal. Chem., 1986, 197,195-208.

[27] Liu, Y.C.; Qiu, X.P.; Huang, Y.Q.; Zhu, W.T. Methanol electrooxidation on mesocarbon microbead supported Pt catalysts. Carbon, 2002, 40, 2375-2380.

[28] Faubert, G.; Guay, D.; Dodelet, J.P. Pt Inclusion compounds as Oxygen Reduction Catalysts in polymer- Electrolyte Fuel Cells. $J$. Electrochem. Soc., 1998, 145, 2985-2992.

This is an open access article licensed under the terms of the Creative Commons Attribution Non-Commercial License (http://creativecommons.org/licenses/by-nc/ $3.0 /$ ) which permits unrestricted, non-commercial use, distribution and reproduction in any medium, provided the work is properly cited 